DOI https://doi.org/10.30525/978-9934-26-006-3-9

\title{
АНАЛІЗ ПЛАСТИКОВОГО ПАКОВАННЯ ТОВАРІВ ПОБУТОВОЇ ХІМІЇ У МІСТІ ВОЛОДИМИРЕЦЬ (РІВНЕНСЬКА ОБЛ., УКРАЇНА)
}

\author{
Галаган О. К. \\ кандидат біологічних наук, доиент, \\ дочент кафедри біології, екології та методики їх навчання \\ Кременещька обласна гуманітарно-педагогічна академія \\ імені Тараса Шевченка \\ Блищик С. C. \\ студентка 41 Е групи \\ Кременецька обласна гуманітарно-педагогічна академія \\ імені Тараса Шевченка \\ м. Кременець, Тернопільська область, Украӥна
}

Пластик увійшов до життя людей як замінник природної сировини, такої як метал або дерево, а друга світова війна розкрила багатогранність цього дешевого, легкого $\mathrm{i}$ довговічного матеріалу. У середині 50-х культура споживання американців настільки змінилася, що їй дали назву - «throwaway living», одноразовий стиль життя, а зовсім нещодавно вчені вперше виявили частинки мікропластику у тілі людини. Тому дедалі більше країн обмежує продаж одноразового посуду і пакетів, а $\mathrm{OOH} \mathrm{визначила} \mathrm{полімерне} \mathrm{забруднення} \mathrm{найголовнішою} \mathrm{загрозою} \mathrm{для}$ подальшого збереження чисельності планети [1].

Товари побутової хімії - це непродовольчі хімічні речовини, засоби догляду за одягом, приміщеннями, автомобілями, посудом тощо, які зазвичай зустрічаються і використовуються в домогосподарстві. До них традиційно відносять також дезінфектори, репеленти та інші хімічні засоби, які призначені, зокрема, для очищення певних поверхонь, боротьби зі шкідниками та загальних гігієнічних потреб. Умовно товари побутової хімію розділяють на дві категорії: 1 - засоби для прання: пральні порошки, гелі для прання, вибілювачі та інші; 2 - засоби для миття посуду. Окремо виділяють засоби для очищення та дезінфекції, засоби для омивання скла автомобілів тощо. Одними 3 найбільших світових виробників побутової хімії $\epsilon$ компанії Procter \& Gamble, Henkel, Reckitt Benckiser та Unilever. 
Пластик, або пластмаса - це штучний полімер. Назвали його так тому, що це пластичний матеріал: при нагріванні або під тиском він розплавляється i піддається формуванню, a після охолодження i затвердіння зберігає свою форму. Якості, які зробили пластик цінним i популярним, - довговічність і стійкість до руйнування, перетворили його на ворога природи.

Проблема пластику полягає не лише у великій кількості відходів, які не розкладаються сотні років, але й у його впливові на організм людини. Вчені стверджують, що до 80\% виявлених в організмі людини «пластикових» речовин потрапляють туди 3 будівельних та оздоблювальних матеріалів, зокрема, з таких популярних пластикових вікон, меблів та посуду [2, с. 201].

Сьогодні відомо біля 150 видів пластику. Типи пластику і коди для них визначені «Спілкою пластикової промисловості» (SPI). Коди SPI широко застосовуються для позначення типу пакувального матеріалу. Така практика є обов'язковою в багатьох країнах [1].

Для сортування пластику розроблена інтернаціональна система маркування. Вона виглядає як трикутник утворений стрілками 3 цифрою всередині. Під трикутником разом із цифрою, або замість цифри може бути вказаний літерний код пластику [4]. Це позначення знак переробки, який поділяє всі пластмаси на певні групи. Це робиться для полегшення подальшої переробки. В побуті за цим знаком можна визначити для яких цілей можна використовувати пластиковий виріб, а в яких випадках краще відмовитись від використання виробу.

Основні типи пластику, які широко застосовуються для упаковки товарів:

1. Поліетилентерефталат (РЕТЕ/РЕT)

2. Поліетилен високої щільності (HDPE)

3. Полівінілхлорид (PVC / V)

4. Поліетилен низької щільності (LDPE)

5. Поліпропілен (РP)

6. Полістирол (PS)

7. Інші види пластмас (OTHER)

Але не всі типи пластику можна переробляти. У контейнер для пластику можна класти тільки упаковку, на якій зображений трикутник 3 цифрою (від 1-7, крім 3 та 5) або наступними буквами: РET або PETE, HDPE або PEHD, LDP або PE або PELD, PP, PS. Не підлягає переробці пластик, на якому немає маркування або стоїть № 3 чи № 7. До того ж не кожна сортувальна лінія працює 3 переробниками цих видів пластику. Найчастіше збирають поліетилентерефталат (РЕТЕ/РЕТ - 1) 
та поліетилен високої щільності (HDPE - 2), а тому слід обирати продукцію побутової хімії у пакованні з таких типів пластику.

Товари побутової хімії найчастіше пакуються у пластикову тару. На споживання і продаж засобів побутової хімії не впливає ні фактор сезонності, ні особливим чином кризовий стан економіки. Ця продукція завжди має попит, єдине, що під час кризи збільшилося споживання продукції економ-сегменту. У Свропі в середньому цей показник в 2-3 рази вище, ніж у нас. Так в Німеччині середньостатистичний житель купує прального порошку 10-12 кг в рік, в Англії - 14,2 кг на рік, у Франції споживають 15,6 кг порошку на рік однією людиною. А в Америці цей показник досягає рівня 28 кг в рік на споживача. Як і багато інших ринків товарів в Україні, ринок побутової хімії $є$ досить перспективним і має позитивну тенденцію зростання [4, с. 15].

Було проведено аналіз пластикового паковання товарів побутової хімії у магазинах та мінімаркетах м. Володимирця. Для дослідження було взято 4 магазини для порівняння - «ТЦ Полісяни», «ТЦ Рікос», «BAZA» та «Полускун». У кожному із них розглядалося по декілька товарів побутової хімії та перевірялась наявність на них вказаного маркованого знаку.

У ході дослідження виявилося, що вироби з поліетилену високої щільності (HDPE) мають найбільший попит серед пластикового паковання цих товарів (рис. 1). Друге місце посідають поліетилентерефталатові вироби (РETE/PET). Меншу частину займають упаковки з полістиролу (PS), полівінілхлориду (PVC / V) та полістиролу (PS). Пластикової упаковки товарів з маркувальним знаком OTHER) інші види пластмас вагалі не було знайдено.

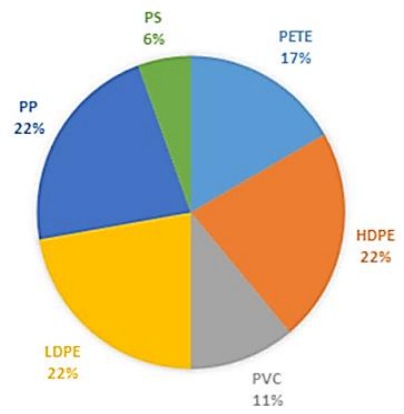

Рис. 1. Кількість маркованого пластикового паковання товарів побутової хімії м. Володимирця 
Шукаючи пункти збору та переробників пластикової тари у місті ми не виявили жодного, що є досить важливою проблемою для містечка 3 досить великою кількістю населення (12 000 осіб). Адже сортування допомагає зменшити кількість відходів, які знаходяться на сміттєзвалищі, завдяки їх подальшій утилізації. Без цього сміття буде тільки накопичуватись, тому що для його розкладання потрібно занадто багато часу (180-200p.). Деякі види пластику взагалі не розкладаються, а при горінні він завдає чималої шкоди для довкілля.

Проаналізувавши результати дослідження ми зробили відповідні висновки і узагальнили рекомендації для зменшення пластикових відходів. Доброякісні вироби з пластику побутової хімії повинні бути виготовлені з полімерних матеріалів, і володіти фізико-механічними i хімічними властивостями в відповідності з потребами ГОСТІВ. Ще одним із обовязкових пунктів, повинно бути наявність контейнерів для сортування різних типів пластику, особливо у великих містах.

Рекомендації щуодо зменшення використання пластикової упаковки серед товарів побутової хіміі:

1. Не купуйте товар упакований в пластик. По можливості відмовтесь від пластикової тари на користь дерев'яній, скляній, порцеляновій або металевій.

2. Уважно слідкуйте за маркуванням пластикової продукції. Не купуйте тару, якщо на ній відсутне маркування, або віддавайте перевагу пластиковому пакованню з маркуванням 1 або 2.

3. Власноруч створюйте речі, а не купуйте їх. Самостійно можна зробити миючий засіб, освіжувач повітря, репеленти тощо.

4. Краще купувати мило, шампунь, піну для гоління в бруску.

5. Дезодоранти в аерозольній упаковці є екологічно шкідливими, бо містять фреон. Замініть свій звичайний дезодорант на алуніт (квасцовий камінь), його можна купити без упаковки, і працює він ефективніше, довше звичайного і найголовніше немає шкідливого впливу на організм людини.

6. Уникайте термічної обробки пластику з низькою термостійкістю.

\section{Література:}

1. Аналіз ринку побутової хімії в Україні. Синтетичні миючі засоби. Блог «Koloro Brand Design» [Електронний ресурс] - Режим доступу: https://koloro.ua/ua/blog/issledovaniya/sinteticheskie-moyuwiesredstva.-analiz-rynka-bytovoj-himii-v-ukraine.html 
2. Клименко М.О., Скрипчук П.М. Метрологія, стандартизація і сертифікація в екології: Підручник. К.: Видавничий центр «Академія», 2006. 368 c.

3. Світ тоне у пластику: масштаби, проблеми та шляхи вирішення [Електронний ресурс] - Режим доступу: http://diyi.org.ua/news/svit-toneu-plastiku-masshtabi-problemi-ta-shlyahi-virishennya

4. Шаповал М.I. Основи стандартизації, управління якістю і сертифікації. Підручник. 3-є вид., перероб. і доп. К.: Європ. ун-т фінансів, інформсистем, менеджменту і бізнесу. 2000. 174 с.

DOI https://doi.org/10.30525/978-9934-26-006-3-10

\title{
ОСОБЛИВОСТІ ВПЛИВУ ПІДВЩЕНОЇ КОНЦЕНТРАЦЇ̈ ІОНІВ К ${ }^{+}$У ВОДІ НА БІОХІМІЧНИЙ СТАТУС ДВОСТУЛКОВОГО МОЛЮСКА ANODONTA CYGNEA (LINNAEUS, 1758)
}

\author{
Красюк Ю. М. \\ кандидат біологічних наук, \\ науковий співробітник \\ Інститут гідробіології Національної академї наук України \\ Худіяш Ю. М. \\ кандидат біологічних наук, \\ стариий науковий співробітник \\ Інститут гідробіології Наџіональної академії наук України \\ м. Київ, Україна
}

Калій $\epsilon$ найважливішим біоелементом, який необхідний для мінерального обміну в усіх без виключення живих організмах, що бере участь у осморегуляції, підтримці кислотно-лужної рівноваги, активуванні ферментів. Проте, гіпертонічні його розчини токсичні для гідробіонтів i мають нервово-паралітичну, гемолітичну та протоплазматичну дію [1, с. 297]. Забруднювачами водойм сполуками калію, в першу чергу, виступають промислові підприємства, які використовують їх у своїх технологічних процесах. В Україні одним із джерел забруднення шкідливими речовинами водних екосистем $€$ наслідки діяльності промислових підприємств i присутність 46 